\title{
Landscape Performance of Buck Roses under Minimal-input Conditions in North-central Texas
}

\author{
Derald Harp ${ }^{1}$, Gaye Hammond ${ }^{2}$, David C. Zlesak ${ }^{3}$, Greg Church ${ }^{4}$, \\ Mark Chamblee ${ }^{5}$, and Steve George ${ }^{6}$
}

AdDitional INDEX wORDs. black spot, drought, powdery mildew, shrub roses

SumMARY. Griffith Buck (Iowa State University) bred roses (Rosa sp.) to survive long, cold winters and hot, humid summers yet still retain their foliage without fungicides. Unfortunately, there is little known about the performance of Buck roses in the southern United States. Thirty-eight Buck rose cultivars were evaluated for flowering, disease resistance, drought tolerance, and overall landscape performance in alkaline soils with no fertilizer, no pesticides, and only limited irrigation. Flowering occurred on a bimodal basis, with the highest per plant mean bloom number ( 16.3 blooms) and bloom coverage (9.7\%) in April, and a second flowering in the fall, with 13.7 blooms per plant and $6.9 \%$ bloom coverage in October. Drought stress symptoms were most evident in October, with a wide range of symptom severity across cultivars. Black spot (Diplocarpon rosae) and powdery mildew (Podosphaeva pannosa) incidence were rare across all roses and years. Landscape performance scores, rated using a 0 to 10 scale with 10 representing a perfect plant and 0 a dead plant, were highest in April (6.5) and lowest in June (4.6) and July (4.6). Landscape performance was not correlated with bloom number or coverage. While unable to recommend many of the Buck roses for northcentral Texas, the cultivars April Moon and Freckles, and possibly a few other roses, can join Carefree Beauty ${ }^{\mathrm{TM}}$ (BUCbi) as recommended roses for the area.

$\mathrm{R}$ oses are the most popular woody ornamental in the United States (Waliczek et al., 2015) and around the world. There are many different designations of roses, ranging from the single-flowered stems of the hybrid teas to the multiple blooms per stem of polyantha and shrub roses (American Rose Society, 2007). Unfortunately, many roses, especially hybrid teas, require frequent fertilization and irrigation, are highly susceptible to disease, especially black spot and powdery mildew, and pests (Mackay et al., 2008). Consumers today are increasingly unwilling to use high-maintenance plants and desire a rose that is medium sized ( 3 to $4 \mathrm{ft}$ tall and wide), disease resistant, pest tolerant, and blooms throughout the growing season (Grygorczyk et al., 2013; Waliczek et al., 2015).

One of the most significant and prolific public rose breeding programs in the United States was Griffith Buck's program at Iowa State University (ISU). Dr. Buck served as a professor at ISU from 1948 to 1985. These hybrids were released from 1962 until his death in 1991, and posthumously for many years thereafter (Minot, 2019). Reiman Gardens at ISU grows 93 Buck roses in their display garden, and they recognize a total of 102 Buck roses (American Public Gardens Association, 2019). Most of Dr. Buck's roses were registered as shrub roses, with a limited number registered as hybrid teas and grandifloras.

Dr. Buck bred and selected roses for adaptation under low-input conditions in the midwestern United States (e.g., winter survival without insulation, strong growth during the short growing season, and disease resistance). Recent interest in shrub roses has led to renewed interest in his cultivars, especially those with black spot resistance (Bates, 2010; Mueller et al., 2008; Zlesak et al., 2010). During his career, only a limited number of his roses were placed into the national supply chain and were widely available to gardeners. His roses were released through ISU, but this did not necessarily mean there was a commitment in place that, upon release, industry members would commercialize the roses. It was in the early 1990s that a strong effort by a limited number of specialty mail order nurseries gathered Dr. Buck's roses, confirmed their identity, propagated them, and made them available to the public. Buck family members gathered these roses and worked with Chamblee's Rose Nursery (Tyler, TX) to release eight of them in 2010.

Dr. Buck's goal was to develop winter-hardy roses that would retain their foliage without fungicides, and some of his cultivars are in the parentage of many of today's most popular landscape roses (Bates, 2010). For example, Carefree Beauty ${ }^{\mathrm{TM}}$ is the most widely sold cultivar, and it is in the pedigrees of the currently best-selling roses Knock Out ${ }^{\circledR}$ (RADrazz) and Double Knock Out ${ }^{\circledR}$ (RADtko) (Radler, 2001, 2006). Carefree Beauty ${ }^{\top \mathrm{M}}$ has been recognized as a strong performer under low-input conditions in the south-central United States, and it was designated by Texas A\&M AgriLife Extension Service as the Earth-Kind ${ }^{\circledR}$ Rose of the Year in 2006 (Texas A\&M AgriLife Extension Service, 2019). Carefree Beauty ${ }^{\mathrm{TM}}$ is also a strong performer in north-central Texas, selected as the control cultivar planted in multiple rose cultivar trials (Zlesak et al., 2017; Zuzek et al., 2016).

Many of the Buck roses are resistant to black spot. The Buck rose cultivars Aunt Honey, Carefree Beauty $^{\mathrm{TM}}$, Honeysweet, Earth Song, Prairie Squire, and Pearlie Mae had strong black spot resistance and maintained high landscape quality, even under moderate disease pressure (Mueller et al., 2008). Black spot consists of many races, distinguished from one another based on their ability to infect common roses (Zlesak et al., 2010). When challenged with black spot races 3,8 , and 9 , the Buck rose cultivars Barn Dance,

\begin{tabular}{llll}
\hline $\begin{array}{l}\text { Units } \\
\begin{array}{l}\text { To convert U.S. to SI, } \\
\text { multiply by }\end{array}\end{array}$ & U.S. unit & SI unit & $\begin{array}{l}\text { To convert SI to U.S., } \\
\text { multiply by }\end{array}$ \\
\hline 0.3048 & $\mathrm{ft}$ & $\mathrm{m}$ & 3.2808 \\
3.7854 & gal & $\mathrm{L}$ & 0.2642 \\
2.54 & inch $(\mathrm{es})$ & $\mathrm{cm}$ & 0.3937 \\
25.4 & inch $(\mathrm{es})$ & $\mathrm{mm}$ & 0.0394 \\
$\left({ }^{\circ} \mathrm{F}-32\right) \div 1.8$ & ${ }^{\circ} \mathrm{F}$ & ${ }^{\circ} \mathrm{C}$ & $\left({ }^{\circ} \mathrm{C} \times 1.8\right)+32$
\end{tabular}


Quietness, and Square Dancer were resistant to two of the three races, and the cultivars Country Dancer, Folksinger, Prairie Harvest, and Winter Sunset were resistant to one of the three races (Zlesak et al., 2010).

Unfortunately, other than Carefree Beauty $^{\top \mathrm{M}}$, little information is available regarding the use of Buck roses in warmer climates. Identifying roses with strong landscape performance, resistance to pests and diseases, and a tolerance for the heat and drought common in north-central Texas can be difficult (Harp et al., 2019; Mackay et al., 2008; Zlesak et al., 2017). The objective of this study was to evaluate a selection of Buck roses under minimalinput conditions in north-central Texas.

\section{Materials and methods}

Planting SITE, PLANT INSTALLATION, AND MAINTENANCE.

$\overline{\text { Received for publication } 18 \text { Nov. 2019. Accepted for }}$ publication 28 Jan. 2020.

Published online 6 March 2020

${ }^{1}$ College of Agricultural Sciences and Natural Resources, Texas A\&M University-Commerce, P.O. Box 3011, Commerce, TX 75429

${ }^{2}$ Houston Rose Society, 5020 Montrose Boulevard, 9th Floor, Houston, TX 77006

${ }^{3}$ University of Wisconsin-River Falls, 410 South 3rd Street, River Falls, WI 54022

${ }^{4}$ Arborilogical Services, Inc., 16 Steel Road, Wylie, TX 75098

${ }^{5}$ Vital Earth Resources, Inc., 706 E. Broadway Avenue, Gladewater, TX 75647

${ }^{6}$ Texas A\&M Research and Extension Center, 17360 Coit Road, Dallas, TX 75252

We thank the Houston Rose Society, the city of Farmers Branch, TX, and Chamblee's Rose Nursery for their funding and generous support of this project. We also thank Pam Smith and the city of Farmers Branch landscape maintenance staff, the staff of Chamblee's Rose Nursery, and the many generous volunteers (e.g., nearby Rose Society members and local residents) who helped make this research possible. We also express our sincere appreciation to the Buck family for being so gracious as to provide us access to the last group of cultivars hybridized by Dr. Griffith Buck before their release.

Mention of a trademark, proprietary product, or vendor does not constitute a guarantee or warranty of the product by the authors, Texas A\&M UniversityCommerce, Texas A\&M University, Texas A\&M AgriLife Extension Service, University of Wisconsin-River Falls, the Houston Rose Society, Arborilogical Services, Vital Earth Resources, or the city of Farmers Branch, and does not imply its approval to the exclusion of other products or vendors that also may be suitable.

D.H. is the corresponding author. E-mail: Derald. Harp@tamuc.edu.

This is an open access article distributed under the CC BY-NC-ND license (https://creativecommons.org/ licenses/by-nc-nd/4.0/).

https://doi.org/10.21273/HORTTECH04539-19
This study was conducted at the Farmers Branch Rose Gardens (U.S. Department of Agriculture hardiness zone 8, American Horticultural Society heat zone 8) from Jan. 2008 through Oct. 2011, with drought scores continued through Oct. 2012. Soils in the study area included Houston Black clay $(\approx 60 \%)$ (fine, smectitic, thermic, Udic Haplusterts, $\mathrm{pH}$ 7.9) and Lewisville silty clay $(\approx 40 \%)$ (fine-silty, mixed, active, thermic, Udic Calciustolls, pH 8.2).

Ten-foot-wide trial beds were created by killing existing vegetation with glyphosate and tilling the soil to a depth of 12 inches, incorporating the remaining dead vegetation as organic matter. Drip irrigation was installed in the middle of each bed, with lines parallel to each other, spaced 18 inches apart and with emitters every 18 inches $(0.6 \mathrm{gal} / \mathrm{h})$. A 10 -ft-wide row of common bermudagrass ( Cynodon dactylon) was maintained between beds. Individual roses were planted $8 \mathrm{ft}$ apart, centered between the irrigation lines. Beds were covered with shredded tree trimmings to a depth of 4 inches and maintained at this depth throughout the study. A single rose ('Belinda's Dream' or 'Duchesse de Brabant') was planted at the ends of each row to minimize border effects.

Plants were irrigated weekly during year 1 to ensure establishment. In year 2 , irrigation was applied on an asneeded basis to maintain plant quality. The intent was to not irrigate during years 3 and 4 of the study. However, in 2010 and 2011, northcentral Texas suffered through extreme heat, with 25 and $70 \mathrm{~d}$ above $100{ }^{\circ} \mathrm{F}$, respectively, and below normal precipitation that led to exceptional drought conditions. This was the most intense drought in recorded Texas history (Harp et al., 2019; Nielsen-Gammon, 2011). To prevent plant death, we applied supplemental irrigation sufficient to bring soil moisture levels to field capacity, three different times in 2010 and again in 2011, during July and August.

Plants were maintained using Earth-Kind ${ }^{\circledR}$ protocols (Harp et al., 2009; Zlesak et al., 2015). No compost was incorporated into the soil, and we used no supplemental fertilizers, with nutrients supplied only by decomposing mulch. No insecticides, fungicides, or other sprays were applied during the study, and plants were pruned only to prevent large cultivars from encroaching onto adjacent roses or the grass walkways.

Plant materials. Thirty-eight Buck rose cultivars were selected for field evaluation based on recommendations by rosarians familiar with Buck roses and growing conditions in north-central Texas (Table 1 ). These cultivars included nine previously unreleased roses.

All roses were propagated from stem cuttings and planted as 2-yearold, container-grown plants in Dec. 2008.

Plant Quality assessment. From 2009 to 2011 , a specialist from either Texas A\&M UniversityCommerce or the Texas A\&M AgriLife Extension Service evaluated roses once monthly during the growing season (April-October, except Apr. 2009) for 1) landscape performance; 2) bloom number; 3 ) percent bloom coverage, defined as the estimated percentage of the plant canopy covered in blooms; and 4) drought stress. Carefree Beauty ${ }^{\mathrm{TM}}$ was a strong performer in previous studies in northcentral Texas (Mackay et al., 2008; Zlesak et al., 2017) and used as an experimental standard.

To determine landscape performance, the rating scale (adapted from Mackay et al., 2008) used scores from 0 to 10 , based on three indices: 1 ) flower quantity and quality; 2 ) foliage quantity and quality; and 3) plant habit and vigor. Ratings were as follows: $10=$ no deductions for all three indices, $9=$ slight deduction for one index, 8 = slight deductions for two indices, $7=$ slight deductions for three indices or moderate deduction for one index, $6=$ moderate deduction for one index and slight deduction for one index, $5=$ moderate deduction for one index and slight deductions for two indices, $4=$ moderate deductions for two indices, $3=$ severe deduction for one index and moderate deduction for one index, $2=$ severe deductions for two indices, $1=$ severe deductions for three indices, $0=$ a dead plant.

Drought stress ratings were determined by estimating the percentage of the plant exhibiting drought stress symptoms. Leaf wilting, stem tip wilting, marginal leaf browning and necrosis, and yellowing and chlorosis of foliage were used as indicators 
Table 1. The commercial class, flower color, and year of introduction of 38 Buck roses.

\begin{tabular}{|c|c|c|c|}
\hline Cultivar $^{z}$ & $\begin{array}{c}\text { Commercial } \\
\text { class }^{\mathrm{y}}\end{array}$ & Flower color ${ }^{y}$ & $\begin{array}{c}\text { Yr of } \\
\text { introduction }^{y}\end{array}$ \\
\hline Almost Heaven & Shrub & Pink blend & $-^{x}$ \\
\hline American Legacy & Shrub & Deep pink & 2010 \\
\hline Amiga Mia & Shrub & Medium pink & 1978 \\
\hline April Moon & Shrub & Medium yellow & 1985 \\
\hline Barn Dance & Shrub & Orange pink & 1975 \\
\hline Brave Patriot & Shrub & Medium red & 2003 \\
\hline Bright Melody & Shrub & Medium red & 1985 \\
\hline Butterfly Magic & Shrub & Orange pink & 2010 \\
\hline Calico Gal & Shrub & Apricot blend & 2010 \\
\hline Carefree Beauty $^{\mathrm{TM}}$ (BUCbi) & Shrub & Medium pink & 1979 \\
\hline Cinderella's Song & Shrub & Pink blend & 2010 \\
\hline Cinnamon Spice & Shrub & Orange pink & 2010 \\
\hline Country Dancer & Shrub & Deep pink & 1972 \\
\hline Dorcas & Shrub & Pink blend & 1985 \\
\hline Do-Si-Do & Shrub & Medium pink & 1985 \\
\hline Earth Song & Grandiflora & Deep pink & 1976 \\
\hline Folksinger & Shrub & Yellow blend & 1985 \\
\hline Freckles & Shrub & Pink blend & 1976 \\
\hline Grandpa's Boy & Shrub & Medium red & 2010 \\
\hline Griff's Red & Shrub & Medium red & 2001 \\
\hline Joseph F. Lamb & Shrub & Dark red & 1989 \\
\hline Kathy's Find & Shrub & Medium pink & — $^{\mathrm{w}}$ \\
\hline Malaguena & Shrub & Medium pink & 1976 \\
\hline Mary Susan & Shrub & Orange pink & 2010 \\
\hline Maytime & Shrub & Pink blend & 1975 \\
\hline Piccolo Pete & Shrub & Medium red & 1985 \\
\hline Pipe Dreams & Shrub & Medium pink & 1985 \\
\hline Polonaise & Shrub & Deep pink & 1984 \\
\hline Prairie Breeze & Shrub & Mauve & 1979 \\
\hline Prairie Harvest & Shrub & Light yellow & 1985 \\
\hline Quietness & Shrub & Light pink & 2003 \\
\hline Red Dream & Shrub & Red blend & - $^{\mathrm{v}}$ \\
\hline September Song & Grandiflora & Apricot blend & 1981 \\
\hline Simon Estes & Shrub & Medium pink & 2006 \\
\hline Square Dancer & Shrub & Deep pink & 1972 \\
\hline Summer Honey & Shrub & Apricot blend & 2010 \\
\hline Summer Wind & Shrub & Orange pink & 1975 \\
\hline Winter Sunset & Shrub & Yellow blend & 1997 \\
\hline
\end{tabular}

${ }^{\mathrm{z}}$ Cultivar name or trademark followed by cultivar name in parentheses

${ }^{y}$ Reported by American Rose Society (2007) or HelpMeFind (2020).

‘Almost Heaven' has been propagated and shared with family and friends and, to date, has not been commercially introduced.

w'Kathy's Find' is a Buck rose bred in 1975 (HelpMeFind, 2020) and was shared as a numbered seedling with colleagues at the Morden Research Station in Morden, Mannitoba. In the early 1990s, Kathy Zuzek saw it at the Morden Research Station and helped propagate and distribute it to specialty rose nurseries (K. Zuzek, personal communication). The official introduction date is unclear.

'Red Dream' was bred in 1977, and the U.S. plant patent was granted in 1986 (HelpMeFind, 2020). The official introduction date is unclear.

of drought stress (Harp et al., 2015, 2019; Pinior et al., 2005). To provide an accurate assessment of drought stress performance under normal summer conditions, we also collected drought stress ratings through 2012. No supplemental irrigation was applied during the 2012 growing season.

An AgriLife specialist assessed roses for black spot (BS) and powdery mildew (PM) five times in 2009
(May, June, August, September, and November), four times in 2010 (April, June, July, and September), and three times in 2011 (May, August, and September). Plants were scored using a 0 to 5 scale with $0=$ no observable disease, $\mathrm{l}=$ up to $20 \%$ of the plant infected, 2 = between $21 \%$ and $40 \%$ of the plant infected, $3=$ between $41 \%$ and $60 \%$ of the plant infected, $4=$ between $61 \%$ and $80 \%$ of the plant infected, and $5=>80 \%$ of the plant infected. At the time of the study, rose rosette disease (Emarovirus sp.) was not common in the area.

EXPERIMENTAL DESIGN AND DATA ANALYSIS. Experimental design was a randomized complete block, with beds divided into four blocks, and each rose cultivar represented once in each of the four blocks.

Percentage data (bloom coverage and drought) were transformed using arcsine square root transformations, and then back transformed for publication purposes. As determined by the UNIVARIATE procedure (SAS version 9.4; SAS Institute, Cary, NC), data sets did not satisfy Kolmogorov-Smirnov $(P<0.05)$ normality tests, so data were analyzed using the GLIMMIX procedure (SAS version 9.4) with a Newton-Raphson Optimization (Stroup, 2015). Months were controlled as a repeated variable, and data analyzed using a covariance structure selected by using the Akaike's information criterion (AIC) score, and Fisher's least significant difference was used for means separation $(\alpha=0.05)$.

A Pearson Correlation test was conducted using the CORR procedure (SAS version 9.4) to ascertain the relationship between bloom number and coverage with landscape performance.

\section{Results}

LANDSCAPE PERFORMANCE. Across all rose cultivars, landscape performance was best in April (6.5), with average scores 1.3 points higher when compared with May (5.2), the second highest scoring month. September (5.0) and October (4.9) followed, with the lowest scores found in June (4.6), July (4.6), and August (4.7) (Table 2).

The Buck rose cultivars April Moon, Freckles, Carefree Beauty ${ }^{\mathrm{TM}}$, and Red Dream had the highest landscape performance scores, with average scores across all years and months of $6.7,6.4,6.3$, and 6.3 , respectively. These roses outperformed the remaining rose cultivars, with only Square Dancer, Prairie Breeze, Country Dancer, and Barn Dance having statistically similar scores to Carefree Beauty $^{\text {TM }}$ (Table 3 ).

Many Buck rose cultivars display good landscape performance in cooler 
Table 2. Average overall landscape performance ratings of Buck roses grown in north-central Texas over time.

\begin{tabular}{lcccc}
\hline & \multicolumn{4}{c}{ Landscape performance $(\mathbf{0}-10 \text { scale })^{\mathrm{z}}$} \\
\cline { 2 - 5 } Month & $\begin{array}{c}\text { Avg across } \\
\text { all years }\end{array}$ & $\mathbf{2 0 0 9}$ & $\mathbf{2 0 1 0}$ & $\mathbf{2 0 1 1}$ \\
\cline { 2 - 5 } April & $6.5 \mathrm{a}^{\mathrm{y}}$ & $\mathrm{n} / \mathrm{a}$ & $6.7 \pm 0.16$ & $6.3 \pm 0.12$ \\
May & $5.2 \mathrm{~b}$ & $5.5 \pm 0.14$ & $5.0 \pm 0.12$ & $5.3 \pm 0.15$ \\
June & $4.6 \mathrm{e}$ & $4.6 \pm 0.11$ & $5.1 \pm 0.11$ & $4.1 \pm 0.14$ \\
July & $4.6 \mathrm{e}$ & $5.3 \pm 0.08$ & $4.5 \pm 0.15$ & $4.0 \pm 0.13$ \\
August & $4.7 \mathrm{de}$ & $5.7 \pm 0.11$ & $3.9 \pm 0.12$ & $4.5 \pm 0.12$ \\
September & $5.0 \mathrm{c}$ & $5.0 \pm 0.11$ & $5.0 \pm 0.11$ & $4.8 \pm 0.12$ \\
October & $4.9 \mathrm{~cd}$ & $5.0 \pm 0.12$ & $4.4 \pm 0.10$ & $5.2 \pm 0.14$ \\
\hline
\end{tabular}

${ }^{\mathrm{z}}$ Landscape performance rating was determined by using a criterion-referenced scale from 0 (dead plant) to 10 (strong performance), with three indices (flower quantity and quality, foliage quantity and quality, and plant habit and vigor) as described by Mackay et al. (2008). Ratings were recorded once monthly during the growing season. Scores provided are averages across all roses for that particular month.

'Statistical analysis conducted using the GLIMMIX procedure (SAS version 9.4; SAS Institute, Cary, NC), controlling for month as a repeated variable, and means separated using Fisher's least significant difference with an $\alpha=0.05$. Scores within columns followed by the same letter are not significantly different.

climates (Zuzek and Hokanson, 2007); but unfortunately, a significant number of the Buck roses in this study did not perform well in the northcentral Texas heat and drought. 'Mary Susan' (3.4) was the most poorly-rated rose, followed closely by the cultivar Grandpa's Boy (Table 3).

BLOOM NUMBER. Rose cultivars had the greatest average number of blooms in April (16.3) and October (13.2), followed closely by May (10.8). Rose bloom numbers dropped in the hottest months of the year, with numbers in July (4.5), August (4.0), and September (5.2) being the lowest of the year.

Rose cultivars with the highest average number of blooms per monthly rating included April Moon (29.9), Bright Melody (28.9), and Do-Si-Do (26.2), compared with 17.0 blooms for Carefree Beauty ${ }^{\mathrm{TM}}$ (Table 3). 'Grandpa's Boy' had the lowest average bloom number (0.9), followed by the cultivars September Song (2.4) and Summer Honey (3.8).

Heavy rainfall in Apr. 2010 and Oct. 2011 may have helped increase average bloom numbers. In Apr. 2010 , across all cultivars, roses averaged 22.6 blooms per plant. followed by July with 8.2 and 8.0 in May. In 2011 , roses averaged 28.3 blooms in October but 11.3 or fewer in all other months. 'April Moon' was a particularly strong performer in this regard. 'April Moon' averaged 73 blooms in Apr. 2010, with a maximum of 112 blooms, but averaged three blooms per plant in Aug. 2010, and three plants had no blooms. In 2011, 'April Moon' averaged 23.7 blooms per plant per month, with 103 blooms per plant in October. If October counts are not included, 'April Moon' averaged only 10.8 blooms per plant per month in 2011.

Among those with the lowest bloom numbers, 'Grandpa's Boy' rarely bloomed in 2010 or 2011 , with no single plant having more than five blooms in any month during the study period, and, across all specimens, only one plant had a bloom in June, July, Aug., or Sept. 2010 and 2011. Similar patterns emerged for all those roses with the lowest bloom numbers.

Bloom coverage. Roses had the highest bloom coverage in April $(9.7 \%)$, followed by May (7.2\%) and October (6.9\%). Bloom coverage dropped during the summer, with the lowest ratings recorded in August $(2.8 \%)$, July $(3.0 \%)$, and September (3.3\%).

'Mary Susan' (10.4\%) had the highest average bloom coverage, followed closely by the cultivars Almost Heaven (9.7\%), Dorcas (9.3\%), Barn Dance $(8.7 \%)$, American Legacy $(8.4 \%)$, Brave Patriot $(7.8 \%)$, Maytime (7.7\%), Do-Si-Do (7.5\%), Pipe Dreams (7.3\%), April Moon (7.1\%), Cinnamon Spice (6.8\%), and Country Dancer (6.8\%). Rose cultivars with the lowest bloom coverage included Grandpa's Boy (0.2\%), September Song (1.6\%), Kathy's Find (3.1\%), Summer Honey $(3.2 \%)$, Piccolo Pete (3.2\%), and Prairie Breeze (3.4\%). Carefree Beauty ${ }^{\mathrm{TM}}(4.1 \%)$ ranked near the middle of all roses tested.

Drought stress. Across all 3 years, drought stress symptoms developed in June and July $(14.0 \%$ and $12.5 \%$, respectively), and became more severe throughout the remainder of the growing season, with the most symptoms observed in October (30.5\%), September $(26.7 \%)$, and August $(17.4 \%)$. Symptoms were mostly absent during April (3.2\%) and May $(0.3 \%)$.

Across cultivars, Almost Heaven displayed the fewest drought symptoms $(6.7 \%)$, followed closely by Cinnamon Spice $(7.5 \%)$, Amiga Mia (7.7\%), April Moon (7.7\%), and 15 additional roses with statistically similar drought stress scores (Table 3). 'Griff's Red' was the poorest performer, with a mean drought stress score of $24.6 \%$, followed by the cultivars Pipe Dreams (19.4\%), Grandpa's Boy (18.4\%), Piccolo Pete (18.2\%), Mary Susan (17.6\%), and two additional roses with similarly high drought stress scores (Table 3 ).

The complete removal of irrigation in 2012, a growing season with more normal weather, severely and negatively influenced drought stress scores, with mean scores increasing to $37.7 \%$, compared with $7.7 \%$ in 2011 and $2.5 \%$ in 2010 . By the end of the study, mean drought stress scores had reached $67.4 \%$ across all roses and 13 cultivars had drought stress scores of $80 \%$ or higher. However, the cultivars April Moon, Carefree Beauty ${ }^{\mathrm{TM}}$, and Kathy's Find all had final drought stress scores under 33\%.

BLACK sPOT. Black spot symptoms were most severe in November, followed by May and June. Symptoms abated during the late summer, with the lowest scores recorded in August and September. Black spot scores were greatest in years 1 and 2 , with significantly lower scores $(P \leq 0.05)$ in year 3 .

The cultivars Carefree Beauty ${ }^{\mathrm{TM}}$, Square Dancer, Simon Estes, Kathy's Find, and Country Dancer had the lowest average black spot scores, all averaging 0.7 or lower (Table 3 ). While Buck roses are known for black spot resistance, six rose cultivars (Winter Sunset, Cinnamon Spice, Amiga Mia, Cinderella's Song, Mary Susan, and Brave Patriot) had relatively high levels of black spot, with mean scores of 1.6 or greater (Table $3)$.

Powdery Mildew. Powdery mildew appeared only lightly during the study period, and mostly in year 1 . 
Table 3. Monthly ratings, averaged across all years, for landscape performance, bloom number, bloom coverage, drought rating, black spot, and powdery mildew for Buck roses evaluated over 3 years under minimal-input conditions in northcentral Texas.

\begin{tabular}{|c|c|c|c|c|c|c|}
\hline Cultivar $^{\mathrm{z}}$ & $\begin{array}{l}\text { Landscape performance } \\
(0-10 \text { scale })^{\mathrm{y}}\end{array}$ & $\begin{array}{l}\text { Blooms } \\
\text { (no.) }\end{array}$ & $\begin{array}{c}\text { Bloom } \\
\text { coverage }(\%) \\
\end{array}$ & $\begin{array}{c}\text { Drought } \\
(\%)^{\mathrm{x}}\end{array}$ & $\begin{array}{l}\text { Black spot } \\
(0-5 \text { scale })^{w}\end{array}$ & $\begin{array}{l}\text { Powdery mildew } \\
(0-5 \text { scale })^{w} \\
\end{array}$ \\
\hline April Moon & $6.7 \mathrm{a}^{\mathrm{v}}$ & 29.9 a & $7.1 \mathrm{a}-\mathrm{h}$ & $7.7 \mathrm{ab}$ & $0.7 \mathrm{~b}-\mathrm{h}$ & $0.03 \mathrm{ab}$ \\
\hline Freckles & $6.4 \mathrm{ab}$ & $12.9 \mathrm{~d}-\mathrm{h}$ & $5.2 \mathrm{e}-\mathrm{m}$ & $13.0 \mathrm{c}-\mathrm{j}$ & $1.0 \mathrm{~d}-\mathrm{k}$ & $0.28 \mathrm{a}-\mathrm{e}$ \\
\hline Carefree Beauty $^{\mathrm{TM}}$ (BUCbi) & $6.3 \mathrm{a}-\mathrm{c}$ & $17.0 \mathrm{c}-\mathrm{e}$ & $4.1 \mathrm{i}-\mathrm{n}$ & $10.5 \mathrm{a}-\mathrm{g}$ & $0.1 \mathrm{a}$ & $0.07 \mathrm{a}-\mathrm{c}$ \\
\hline Red Dream & $6.3 \mathrm{a}-\mathrm{c}$ & $11.5 \mathrm{e}-\mathrm{i}$ & $3.7 \mathrm{k}-\mathrm{n}$ & $11.4 \mathrm{a}-\mathrm{i}$ & $0.9 c-j$ & $0.25 \mathrm{a}-\mathrm{e}$ \\
\hline Square Dancer & $6.1 \mathrm{~b}-\mathrm{d}$ & $11.5 \mathrm{e}-\mathrm{i}$ & $4.7 \mathrm{f}-\mathrm{m}$ & $17.3 \mathrm{i}-1$ & $0.4 \mathrm{ab}$ & $0.13 \mathrm{a}-\mathrm{e}$ \\
\hline Barn Dance & $5.8 \mathrm{c}-\mathrm{f}$ & $21.5 \mathrm{bc}$ & $8.7 \mathrm{a}-\mathrm{d}$ & $14.6 \mathrm{e}-\mathrm{j}$ & $0.9 c-j$ & $0.08 \mathrm{a}-\mathrm{c}$ \\
\hline Simon Estes & $5.7 \mathrm{~d}-\mathrm{g}$ & $12.4 \mathrm{e}-\mathrm{i}$ & $5.8 \mathrm{~d}-1$ & $10.3 \mathrm{a}-\mathrm{g}$ & $0.5 \mathrm{a}-\mathrm{c}$ & $0.14 \mathrm{a}-\mathrm{e}$ \\
\hline Earth Song & $5.6 \mathrm{~d}-\mathrm{h}$ & $13.6 \mathrm{~d}-\mathrm{g}$ & $3.8 \mathrm{j}-\mathrm{n}$ & $14.5 \mathrm{e}-\mathrm{j}$ & $0.7 \mathrm{~b}-\mathrm{h}$ & $0.13 \mathrm{a}-\mathrm{e}$ \\
\hline Kathy's Find & $5.6 \mathrm{~d}-\mathrm{h}$ & $10.3 \mathrm{e}-\mathrm{j}$ & $3.1 \mathrm{~lm}$ & $14.8 \mathrm{f}-\mathrm{j}$ & $0.5 \mathrm{a}-\mathrm{c}$ & $0.03 \mathrm{a}$ \\
\hline Polonaise & $5.6 \mathrm{~d}-\mathrm{h}$ & $21.1 \mathrm{bc}$ & $5.7 \mathrm{~d}-1$ & $9.2 \mathrm{a}-\mathrm{e}$ & $0.6 \mathrm{~b}-\mathrm{e}$ & $0.22 \mathrm{a}-\mathrm{e}$ \\
\hline Bright Melody & $5.5 \mathrm{e}-\mathrm{h}$ & $28.9 \mathrm{a}$ & $5.6 \mathrm{~d}-\mathrm{m}$ & $11.6 \mathrm{a}-\mathrm{j}$ & $1.0 \mathrm{f}-\mathrm{k}$ & $0.21 \mathrm{a}-\mathrm{e}$ \\
\hline Winter Sunset & $5.4 \mathrm{f}-\mathrm{j}$ & $10.8 \mathrm{e}-\mathrm{j}$ & $4.5 \mathrm{~g}-\mathrm{m}$ & $10.7 \mathrm{a}-\mathrm{h}$ & $1.1 \mathrm{~g}-1$ & $0.12 \mathrm{a}-\mathrm{e}$ \\
\hline Butterfly Magic & $5.3 \mathrm{~g}-\mathrm{j}$ & $7.0 \mathrm{~g}-1$ & $5.1 \mathrm{e}-\mathrm{m}$ & $17.5 \mathrm{j}-1$ & $1.2 \mathrm{i}-\mathrm{m}$ & $0.0 \mathrm{a}$ \\
\hline Summer Wind & $5.2 \mathrm{~h}-1$ & $7.8 \mathrm{f}-1$ & $6.6 \mathrm{~b}-\mathrm{j}$ & $14.4 \mathrm{~d}-\mathrm{j}$ & $0.9 c-j$ & $0.0 \mathrm{a}$ \\
\hline Pipe Dreams & $5.2 \mathrm{~h}-1$ & $15.0 \mathrm{c}-\mathrm{f}$ & $7.3 \mathrm{a}-\mathrm{g}$ & $15.5 \mathrm{~g}-\mathrm{j}$ & $0.9 c-j$ & $0.12 \mathrm{a}-\mathrm{e}$ \\
\hline Almost Heaven & $4.9 \mathrm{i}-\mathrm{m}$ & $8.0 \mathrm{f}-1$ & $9.7 \mathrm{ab}$ & $6.7 \mathrm{a}$ & $0.8 \mathrm{~b}-\mathrm{i}$ & $0.05 \mathrm{a}-\mathrm{c}$ \\
\hline Cinnamon Spice & $4.9 \mathrm{i}-\mathrm{m}$ & $5.5 \mathrm{i}-1$ & $6.8 \mathrm{a}-\mathrm{i}$ & $7.5 \mathrm{ab}$ & $1.51-\mathrm{O}$ & $0.08 \mathrm{a}-\mathrm{c}$ \\
\hline Quietness & $4.9 \mathrm{j}-\mathrm{m}$ & $7.6 \mathrm{~g}-1$ & $4.2 \mathrm{~h}-\mathrm{n}$ & 10.9 a-h & $0.6 \mathrm{~b}-\mathrm{f}$ & $0.88 \mathrm{f}$ \\
\hline Dorcas & $4.9 \mathrm{k}-\mathrm{m}$ & $13.0 \mathrm{~d}-\mathrm{h}$ & $9.3 \mathrm{a}-\mathrm{c}$ & $11.7 \mathrm{a}-\mathrm{j}$ & $1.0 \mathrm{f}-\mathrm{k}$ & $0.40 \mathrm{de}$ \\
\hline Prairie Harvest & $4.8 \mathrm{k}-\mathrm{m}$ & $8.5 \mathrm{f}-\mathrm{k}$ & $2.2 \mathrm{no}$ & $16.6 \mathrm{~h}-\mathrm{k}$ & $1.1 \mathrm{~h}-1$ & $0.24 \mathrm{a}-\mathrm{e}$ \\
\hline September Song & $4.71-\mathrm{n}$ & $2.4 \mathrm{kl}$ & $1.6 \mathrm{o}$ & $17.7 \mathrm{j}-1$ & $0.7 \mathrm{~b}-\mathrm{h}$ & $0.25 \mathrm{a}-\mathrm{e}$ \\
\hline Joseph F. Lamb & $4.7 \mathrm{mn}$ & $6.5 \mathrm{~g}-1$ & $6.1 \mathrm{c}-\mathrm{k}$ & 10.9 a-h & $1.4 \mathrm{k}-\mathrm{n}$ & $0.08 \mathrm{a}-\mathrm{c}$ \\
\hline Amiga Mia & $4.6 \mathrm{mn}$ & $13.5 \mathrm{~d}-\mathrm{g}$ & $6.0 \mathrm{c}-\mathrm{k}$ & $7.7 \mathrm{ab}$ & $1.5 \mathrm{~m}-\mathrm{O}$ & $0.02 \mathrm{a}$ \\
\hline Griff's Red & $4.0 \mathrm{pq}$ & $8.2 \mathrm{f}-1$ & $4.6 \mathrm{~g}-\mathrm{m}$ & 24.51 & $1.0 \mathrm{e}-\mathrm{k}$ & $0.25 \mathrm{a}-\mathrm{e}$ \\
\hline Grandpa's Boy & $3.8 \mathrm{qr}$ & 0.91 & $0.2 \mathrm{p}$ & $17.4 \mathrm{i}-1$ & $1.2 \mathrm{i}-\mathrm{m}$ & $0.43 \mathrm{de}$ \\
\hline Mary Susan & $3.4 \mathrm{r}$ & $7.6 \mathrm{f}-1$ & $10.4 \mathrm{a}$ & $17.1 \mathrm{~h}-1$ & 1.8 op & $0.0 \mathrm{a}$ \\
\hline
\end{tabular}

${ }^{\mathrm{z}}$ Cultivar name or trademark followed by cultivar name, if different, in parentheses.

${ }^{y}$ Landscape performance rating was determined using a criterion-referenced scale from 0 (dead plant) to 10 (strong performance), with three indices (flower quantity and quality, foliage quantity and quality, and plant habit and vigor) as described by Mackay et al. (2008). Ratings were recorded once monthly during the growing season. Least square means displayed.

${ }^{x}$ Drought ratings were determined by estimating the percentage of the plant displaying drought symptoms, which included leaf wilting, leaf margin browning and necrosis, chlorosis, and branch dieback, absent observed disease. Data were transformed using arcsine square root transformations and back transformed for publication purposes. Smaller numbers indicate less plant tissue displaying drought stress symptoms.

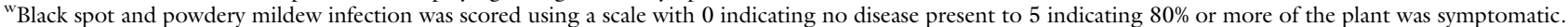

${ }^{v}$ Statistical analysis conducted using the GLIMMIX procedure (SAS version 9.4; SAS Institute, Cary, NC), controlling for month as a repeated variable, and means separated using Fisher's least significant difference with an $\alpha=0.05$; means within columns followed by the same letter are not significantly different.

During year 3, no powdery mildew was detected. Powdery mildew was most common in May (4.0) and June (4.5) of year 1. After year 1 , no powdery mildew was found on plants in August or later.

Even when powdery mildew was observed, most plants displayed only a minor infection. In May 2009, 42 of 150 plants had a powdery mildew score greater than 1. In June 2009, this number dropped to 24. After Aug. 2009, the number of plants that scored 2 or higher never exceeded 4 .

'Quietness' was the most severely affected by powdery mildew, with an average score of 0.88 (Table $3)$. The cultivars Brave Patriot $(0.0)$, Butterfly Magic (0.0), and Summer Wind $(0.0)$ were powdery mildew free throughout the study, and 22 additional rose cultivars had statistically similar mean powdery mildew scores (Table 3).

\section{Discussion and conclusions}

Landscape performance and bloom patterns mimicked previous studies of roses in north-central Texas (Harp et al., 2019; Mackay et al., 
2008; Zlesak et al., 2017), with the best performance and heaviest blooms found in spring (April and May), with plant recovery and a second bloom occurring in the fall (September and October). Disease pressure was highest in the spring, with a recurrence of black spot in the fall, and virtually no disease pressure during July and August.

Landscape performance of Buck roses was usually consistent with previous rose cultivar trials in northcentral Texas (Harp et al., 2019; Mackay et al., 2008; Zlesak et al., 2017). In this study, several rose cultivars performed well, especially April Moon, Freckles, Carefree Beauty $^{\mathrm{TM}}$, Red Dream, Square Dancer, Prairie Breeze, and Country Dancer, whereas others performed poorly. Because this study is limited to comparison of only Buck roses, we must compare with other rose trials in the same regions for an accurate assessment of overall performance. Disappointingly, in a simultaneous study of 60 rose cultivars at the same location using a broader range of roses (Harp et al., 2019), the cultivar April Moon, the rose with the best overall landscape performance in this study, would have ranked below the top 20 . However, this low ranking is indicative of the strong genetics of the roses in that study (Harp et al., 2019), rather than the weakness of the Buck roses tested. If we assume similar performance of Carefree Beauty ${ }^{\mathrm{TM}}$ in our study (6.3) to Mackay et al. (2008) (6.1), it is reasonable to believe the cultivars April Moon and Freckles would have performed as well or better than rose cultivars currently designated as Earth-Kind ${ }^{\circledR}$, such as Caldwell Pink, Cécile Brünner, Monsieur Tillier, Mutabilis, and New Dawn. Similar results can be seen by comparing the highest performers at the Commerce, TX location described in Zlesak et al. (2017). This study was conducted during the same time period, but in a location $\approx 60$ miles to the northeast and in silty loam soils rather than heavy clays. Carefree Beauty ${ }^{\mathrm{TM}}$ landscape performance scores were exceeded by the cultivars Ole, Sunrise Sunset ${ }^{\mathrm{TM}}$, and Yellow Submarine ${ }^{\mathrm{TM}}$, and equaled by Sea Foam and Sven. It is reasonable to assume that, given the proximity and similar climate, the cultivars April Moon and Freckles would probably have been strong performers in this study as well.

Surprisingly, landscape performance was not correlated with bloom number or coverage, a result likely related to the rapid decline in blooms during the summer, reducing landscape performance to observations of foliage and plant form.

Buck roses, especially Carefree Beauty $^{\mathrm{TM}}$, are known for disease resistance, though resistance may be limited to a race (Leus and Van Huylenbroeck, 2009; Mueller et al., 2008; Whitaker et al., 2007; Zlesak et al., 2010). The cultivars Carefree Beauty ${ }^{\top \mathrm{M}}$, Square Dancer, Kathy's Find, and Simon Estes had the best black spot resistance in this study. Over half (25 of 37) of the roses tested had extremely low powdery mildew scores, with 'Brave Patriot', 'Butterfly Magic', and 'Summer Wind' being powdery mildew free throughout the study.

While disease did affect many rose cultivars, our overall results confirm superior disease resistance in many of the Buck roses. However, we are careful to minimize our conclusions as conditions during the study; i.e., high temperatures, low rainfall, and low relative humidity were not conducive to disease development. For example, the optimum temperature for powdery mildew growth is $72{ }^{\circ} \mathrm{F}$, and fungal growth stops at temperatures above $91{ }^{\circ} \mathrm{F}$ (Longree, 1939; Xu, 1999). Conidial germination and colonization for powdery mildew require a relative humidity of $50 \%$ or higher (Pathak and Chorin, 1969; Rogers, 1959; Xu, 1999). Likewise, black spot conidia do not germinate at temperatures above $91{ }^{\circ} \mathrm{F}$ (Drewes-Alvarez, 2003). Black spot is also a waterdistributed fungus (Saunders, 1966; Whitaker et al., 2007), and relative humidity plays an important role in black spot development (Aronescu, 1934; Gachomo and Kotchoni, 2007). Therefore, favorable climatic conditions for disease pressure generally disappeared in May 2010 and did not return until Oct. 2011.

This study has helped to document the degree to which selected Buck rose cultivars are, or are not, adapted to the climate and alkaline soils in north-central Texas. Disease resistance was good for most cultivars; but, based on landscape performance and flower production in the heat and drought of north-central Texas, we are unable to confidently recommend most of these cultivars. We do believe there is preliminary evidence to further evaluate the Buck rose cultivars April Moon, Freckles, and Red Dream to join Carefree Beauty ${ }^{\top \mathrm{M}}$ for use in north-central Texas landscapes.

\section{Literature cited}

American Public Gardens Association. 2019. Griffith Buck roses: PCN collection listing. 1 Oct. 2019. <https://www.publicgardens. org/programs/plant-collections-network/ collections-showcase/griffith-buck-roses> .

American Rose Society. 2007. Modern roses XXII. Pediment Publ., Battleground, WA.

Aronescu, A. 1934. Diplocarpon rosae from spore germination to haustorium formation. Bull. Torrey Bot. Club 61:291-329.

Bates, M. 2010. Dr. Griffith Buck: A man ahead of his time 1915-1991. Amer. Rose 2010(Sept./Oct.):57-60.

Drewes-Alvarez, R. 2003. Disease/black spot, p. 148-153. In A.V. Roberts, T. Debener, and S. Gudin (eds.). Encyclopedia of rose science. Elsevier Acad. Press, Amsterdam, The Netherlands.

Gachomo, E.W. and S.O. Kotchoni. 2007. Detailed description of developmental growth stages of Diplocarpon rosae in Rosa: A core building block for efficient disease management. Ann. Appl. Bot. 151:233-243.

Grygorczyk, A., S. Mhlanga, and I. Leescaeve. 2013. Hardy rose breeding: Consumer preferences for roses. 1 Oct. 2019. <http://vinelandresearch.com/sites/ default/files/hardy_rose_breeding_ consumer_preferences_for_roses.pdf $>$.

Harp, D.A., D.C. Zlesak, G. Hammond, S. George, and W. Mackay. 2009. EarthKind $^{\mathrm{TM}}$ rose trials-Identifying the world's strongest, most beautiful landscape roses. Floric. Ornam. Biotechnol. 3:166-175.

Harp, D.A., K. Kay, D.C. Zlesak, and S. George. 2015. The effect of rose root size on drought stress tolerance and landscape plant performance. Tex. J. Agr. Nat. Resour. 28:82-88.

Harp, D., G. Hammond, D.C. Zlesak, G. Church, M. Chamblee, and S. George. 2019. Flowering, drought and disease tolerance, and landscape performance of landscape roses grown under low input conditions in north-central Texas. HortTechnology 29:234-240. 
HelpMeFind. 2020. HelpMeFind Roses, clematis, and peonies. 8 Jan. 2020. <https:// www.helpmefind.com/roses>.

Leus, L. and J. Van Huylenbroeck. 2009. Developing resistance to powdery mildew (Podosphaera pannosa (Wallr.:Fr.) de Bary): A challenge for rose breeders. Floric. Ornam. Biotechnol. 3:131-138.

Longree, K. 1939. The effect of temperature and relative humidity on powdery mildew of roses. Cornell Univ. Agr. Exp. Sta. Memoirs 223:1-43.

Mackay, W.A., S.W. George, C. McKenney, J.J. Sloan, R.I. Cabrera, J.A. Reinert, P. Colbaugh, L. Lockett, and W. Crow. 2008. Performance of garden roses in north-central Texas under minimal input conditions. HortTechnology 18:417422

Minot, J.J.G. 2019. Life \& times of Dr. Griffith Buck (1915-1991). 1 Oct. 2019. $<$ https://www.cad.iastate.edu/rose/ aboutbuck>.

Mueller, D.S., M.L. Gleason, N.P. Howell, and E.M. Moran. 2008. Evaluation of Griffith Buck roses for resistance to black spot. HortTechnology 18:588-591.

Nielsen-Gammon, J.W. 2011. The 2011 Texas drought. Tex. Water J. 3:59-95.

Pathak, S. and M. Chorin. 1969. Effects of humidity and temperature conditions on germination of the conidia of Sphaerotheca pannosa (Wallr.) Lev. var rosae Woron. on young and old leaves of three rose varieties. Phytopathol. Mediterr. $7: 123-128$

Pinior, A., G. Grunewaldt-Stöcker, H. von Alten, and R.J. Strasser. 2005. Mycorrhizal impact on drought stress tolerance of rose plants probed by chlorophyll $a$ fluorescence, proline content and visual scoring. Mycorrhiza 15:596-605.

Radler, W.J. 2001. Shrub rose named 'Radrazz'. U.S. Plant Patent 11,836 P2. Filed 13 Jan. 1999. Issued 10 Apr. 2001.

Radler, W.J. 2006. Shrub rose named 'Radtko'. U.S. Plant Patent 16,202 P2. Filed 23 June 2004. Issued 10 Jan. 2006

Rogers, M.N. 1959. Some effects of moisture and host plant susceptibility on the development of powdery mildew of roses, caused by Sphaerotheca pannosa var. rosae. Cornell Univ. Agr. Exp. Sta. Memoirs. 363:3-37.

Saunders, P.J.W. 1966. Epidemiological aspects of blackspot disease of roses caused by Diplocarpon rosae Wolf. Ann. Appl. Botany 58:115-122.

Stroup, W.W. 2015. Rethinking the analysis of non-normal data in plant and soil science. Agron. J. 107:811-827.

Texas A\&M AgriLife Extension Service. 2019. Carefree Beauty receives EarthKind ${ }^{\circledR}$ Rose of the Year Award. 1 Oct. 2019. <https://aggie-horticulture.tamu. edu/earthkindroses /files /2012/06/ CarefreeBeauty.pdf $>$.

Waliczek, T.M., D.J. Holeman, and D.H. Byrne. 2015. Growers' and consumers' knowledge, attitudes and opinions regarding roses available for purchase. Acta Hort. 1064:235-239.
Whitaker, V.M., S.C. Hokanson, and J. Bradeen. 2007. Distribution of rose black spot (Diplocarpon rosae) genetic diversity in eastern North America using amplified fragment length polymorphism and implications for resistance screening. J. Amer. Soc. Hort. Sci. 132:534-540.

Xu, X.M. 1999. Effects of temperature on the latent period of the rose powdery mildew pathogen, Sphaerotheca pannosa. Plant Pathol. 48:662-667.

Zlesak, D.C., D.A. Harp, K. Zuzek, J.J. Sloan, A. Owings, and S.W. George. 2015. Earth-Kind ${ }^{\circledR}$ rose trialing: An international model for the identification of regionally adapted landscape roses. Acta Hort. 1064:123-129.

Zlesak, D.C., R. Nelson, D. Harp, B. Villarreal, N. Howell, J. Griffin, G. Hammond, and S. George. 2017. Performance of landscape roses grown with minimal input in the north-central, central, and south-central United States. HortTechnology 27:718-730.

Zlesak, D.C., V.M. Whitaker, S. George, and S.C. Hokanson. 2010. Evaluation of roses from the Earth-Kind ${ }^{\circledR}$ Trials: Black spot (Diplocarpon rosae Wolf) resistance and ploidy. HortScience 45:1779-1787.

Zuzek, K. and S.C. Hokanson. 2007. Shrub rose breeding at the University of Minnesota. Acta Hort. 751:291-298.

Zuzek, K., D. Zlesak, V.M. Whitaker, S. McNamara, and S.C. Hokanson. 2016. Northern Accents ${ }^{\circledR}$ 'Lena', 'Ole', 'Sigrid', and 'Sven': Four cold-hardy polyantha rose cultivars from the University of Minnesota woody landscape plant breeding program. HortScience 51:296-299. 